\title{
Borwort j̆ut vierten $\mathfrak{A} u f l a g e$.
}

$\mathfrak{E}$

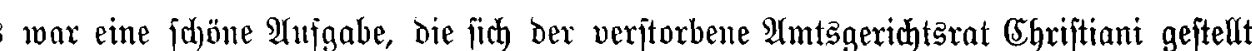
mo die er aud mit (Erjolg erfüllt hat. Drei Mtuflagen feines Buches baben Dafür ge=

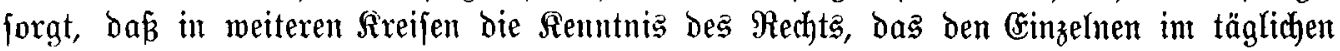

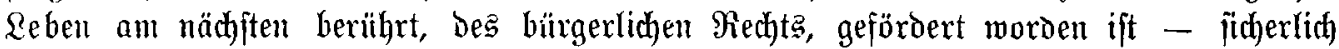
zum gröpten Nugen ber bavon Betroffenen. Demn je vielgejtaltiger Das wirtfdaftlidje,

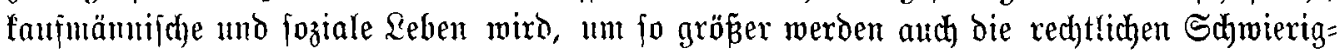

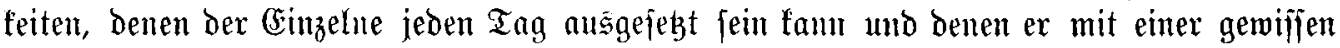

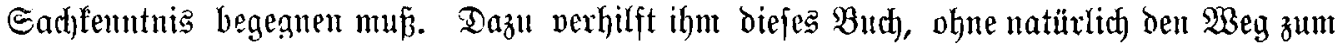

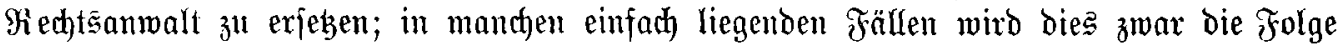
der Reftïre des betreffenden Irtifels diefes Buches feiu, in vielen anderen Fä̈llen wiro

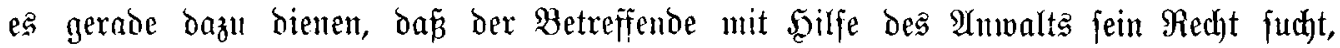

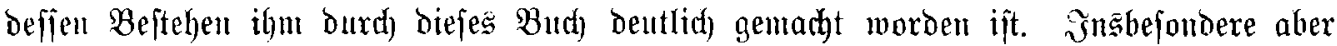
wirb es geeignet jein, ben Rejer feinerjeits uor Srjaben zu berwabren, ba er bie Reunt=

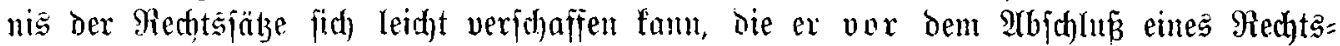
gefdüfts oder vor ber Faffung eines fonfigen (Entfdluffes zu wiffen nötig bat. Aluch

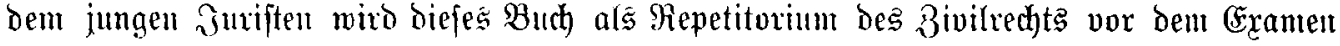
jehr bienlid) jein fünnen.

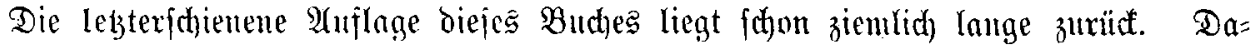

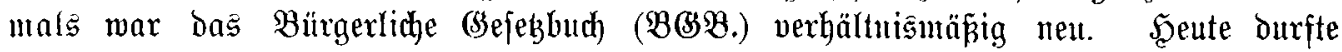

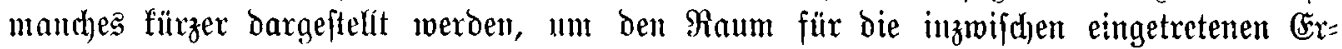

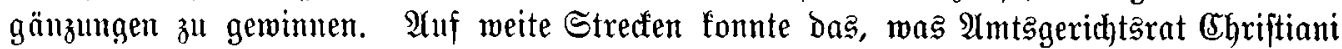
genrbeitet hat, übentommen wernen, benn feine 2 rbeit max gut, war mit Riebe zum Stoffe gemadht, traf ben Ton ber Belehrung bes Nid)tjuriften ganz vorzüglich. Wo man an

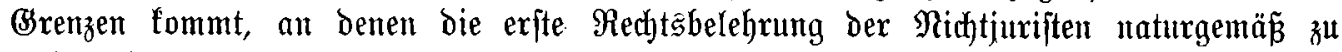

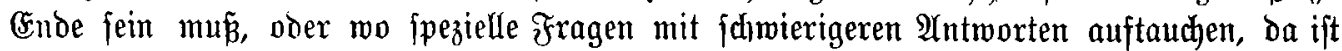
in biefen $\mathfrak{B u d}$ jegt auf bie betreffenden erläuterten Tertausgaben ber Befege in ber

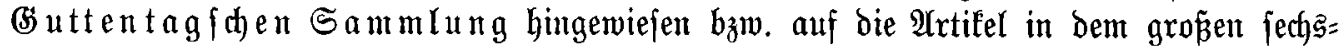

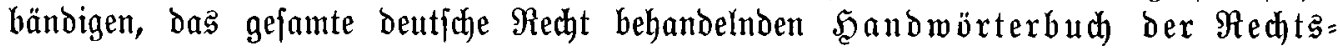
wiffenfhaft herausgegeben won Stier= Somlo und (Elfter.

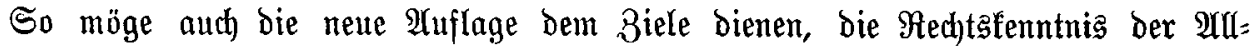

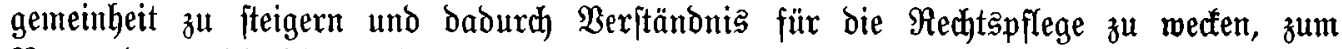
Nuben berer, bie biejes Budh gebraudjen.

Die Benrbeiter. 